\title{
FUNCTIONAL ELASTOMERIC MATERIALS BASED ON BUTADIENE-STYRENE RUBBER AND MAGNETITE
}

\section{Aram A. Khachaturov, Eugene E. Potapov}

Lomonosov Moscow State Institute of Fine Chemical Technologies of MIREA-Russian University of Technology, http://www.chemtech.mirea.ru/

Moscow 119435, Russian Federation

\section{Alexander S. Fionov, Vladimir V. Kolesov}

Kotelnikov Institute of Radioengineering and Electronics of Russian Academy of Sciences, http://cplire.ru/ Moscow 125009, Russian Federation

\section{Eugene M. Ilyin}

Bauman Moscow State Technical University, http://www.bmstu.ru/

Moscow 105005, Russian Federation

xa4aram@mail.ru, fionov@cplire.ru,kvv@cplire.ru,svitar@yandex.ru, evgil45@mail.ru

Abstract. The samples of functional elastomeric composite material based on butadiene-styrene rubber and magnetite with the concentration ranging $0 \ldots .300$ weight parts per 100 weight parts of elastomer were prepared in this work. Stress-strain, electrophysical and microwave properties for these samples were investigated. The concentration dependences of the investigated parameters were obtained. The influence of the magnetic field on the reflectance of samples on the metal in the frequency range $25.86 \ldots 37.5 \mathrm{GHz}$ were investigated. The developed composites can be used as effective radioabsorbing and shielding materials with controlled properties, including gradient ones.

Keywords: magnetite, functional material, butadiene-styrene rubber, electrophysical properties, stress-strain properties, microwave, reflection coefficient, absorption coefficient

UDC 678.046:678.4:539.4:620.22:620.17:621.315.61:621.37.029.6

Bibliography - 20 references

Received 15.11.2018, accepted 21.01.2019

RENSIT, 2019, 11(2):189-198

DOI: 10.17725/rensit.2019.11.189

\section{Contents}

1. Introduction (189)

2. Materials, technologies, research METHODS (190)

3. Results And discussion (194)

4. Conclusion (197)

REFERENCES (197)

\section{INTRODUCTION}

Composite materials are a heterogeneous system that consist of a matrix (polymers, ceramics or metals) in which are distributed high-strength or high-modulus fibers or particles. Dispersionstrengthened polymeric composite materials are a structure consisting of a matrix in which are uniformly distributed the finely-divided particles. Disperse filler particles are introduced into the matrix by special technological methods. In this case, the particles should not actively interact with the matrix and should not dissolve in the matrix until the melting point is reached. The matrix perceives the main load in these materials, in which the reinforcing phase of the filler creates a structure that hinders the movement of dislocations. Dispersion-strengthened polymeric composite materials are, as a rule, isotropic.

Strength and hardness of the composite material depends on the properties of the filler, but the matrix influence to the properties of composite materials. For example, the thermal conductivity and electrical conductivity of the composite material strongly depend on the conductivity of the matrix. The matrix serves as an adhesive that connects the filler particles to the material and gives the product the desired shape. The effect of the filler particles in the matrix is consist to change the mechanical and electrophysical properties: an 
increase in the tensile modulus, an increase in tensile strength, an increase in resistance to impact load, a decrease in strain relaxation and thermal expansion, an increase in electric conductivity, an increase in permittivity and magnetic permeability. Herewith the total cost of the material is reduced, because the cost of the polymer is more than the cost of the filler.

A significant increase in strength at the micro level is determined by statistical factors. The probability that a sample of material contains a sufficiently large defect, which can cause brittle failure, falls with a decrease in the sample. Also, the defect does not increase and does not affect on other fibers if few fibers were destroyed in matrix. In presence of bonding material the defect of the single fiber is not critical because the stress is distributed between other fibers.

The presence of spherical particles of filler in elastomeric material lead to better tensile modulus. The tensile modulus of filled elastomeric material $E_{\mathrm{CM}}$ refers to the tensile modulus of unfilled elastomeric material $E$ as:

$$
E_{\mathrm{CM}}=E(1+2.5 f+14.1 f) \text {, }
$$

where $f-$ is volume concentration of the dispersion phase [1].

In the area of polymeric materials science the great attention is paid to the issue of search new functional fillers. Based thereon we can obtain polymer composite materials, then have unique characteristics, including controlled properties.

Perspective filler for composite materials is magnetite - is ore mineral, pervasive in nature, ferro-ferrite with chemical formula $\mathrm{Fe}_{3} \mathrm{O}_{4}$ and spinel structure.

Magnetite has unique electrophysical and magnetic characteristics. In present significant amount of polymer composite materials based on magnetite have been developed. In literature the large amount papers published extensively, in which shows the results of investigation of structure and properties of same materials, also, possible areas of application of this materials were proposed in this papers. Magnetite sheets with thikness
$200 \ldots 300 \mathrm{~nm}$ were obtained and inverstigated by autors of this paper [2], it can be used in quality of perspective material in spentronic. Based on results of investigation converse magnetostrictive effect for composite material which consist of synthetic isoprene rubber and magnetite in this paper [3] conclusion about possible of application this materials in quality of dynamic absorber and vibration isolator had been made. In biomedical magnetic polymeric microspheres magnetite has been actively applied [4-6]. Polymeric composites based on polystyrene matrix and magnetite can be used in quality sorbtion material $[7,8]$. In this paper [9] the results of investigation of electrophysical, magnetic and microwave absorption properties of materials, which consist of thermoplastic natural rubber filled nanosized magnetite particles, were described. This materials, according to the author, can be used in areas such as radio technology and electronic engineering.

Thus, polymer composite materials, which consist magnetite as active functional component, can be successfully used in many areas of technique. Herewith elastomeric materials filled of natural magnetite were not unvestigated complitely. Therefore, the main purpose of this work was to obtain elastomeric composite materials based on butadienestyrene rubber SKS-30 ARK and magnetite and to study the effect of the filler on the technological, elastic-strength, electrophysical and microwave characteristics of the obtained materials.

\section{MATERIALS, TECHNOLOGIES, RESEARCH METHODS}

In this work, butadiene-styrene rubber SBR1500 (GOST 15627-79 for a similar SKS-30 ARK) was used as a matrix, and magnetite - $\mathrm{Fe}_{3} \mathrm{O}_{4}$, iron-ore concentrate with a mass fraction of iron more than $69.5 \%$ (see Table 1 ), technical specifications 0712-030-001186803-99 
Table 1.

Chemical composition of iron-ore concentrate [11].

\begin{tabular}{|c|c|c|c|c|c|c|c|c|c|c|c|c|c|}
\hline \multicolumn{14}{|c|}{ Content, mass fraction, $\%$} \\
\hline & $\mathrm{Fe}_{2} \mathrm{O}_{3}$ & $\mathrm{FeO}$ & $\mathrm{SiO}_{2}$ & $\mathrm{~A}_{2} \mathrm{O}_{3}$ & \begin{tabular}{|l|l|} 
Mgo \\
\end{tabular} & $\begin{array}{|cc|}\mathrm{COO} \\
\end{array}$ & $\mathrm{Na}_{2} \mathrm{O}$ & $\mathrm{k}_{2} \mathrm{O}$ & $\mathrm{TiO}_{2}$ & $s$ & & & \\
\hline & 66.86 & 2928 & 2.79 & 0.14 & \begin{tabular}{|l|l}
0.21 \\
\end{tabular} & \begin{tabular}{|l}
0.09 \\
\end{tabular} & 0.05 & \begin{tabular}{|l}
.03 \\
\end{tabular} & 0.03 & 0.05 & 0.0 & & \\
\hline
\end{tabular}

(Joint-stock company «Lebedinskii ore mining and processing enterprise»), as a filler.

Particle size distribution of iron-ore concentrate powder were determined with a laser diffractometer Analysette 22 MicroTec Plus. Differential and cumulative grading curve of particles distribution of iron-ore concentrate powder is shows on Fig. 1. It can be seen that particles distribution is unimodal particle size range between 0.1 to $100 \mu \mathrm{m}$. The maximum distribution corresponds to a particle size of about $20 \mu \mathrm{m}$. As can be seen from the integral curve, $90 \%$ of the iron-ore concentrate particles are smaller than $40 \mu \mathrm{m}$.

Fig. 2 shows the diffraction pattern of ironore concentrate powder, which was shoted using diffractometer HZG-4 (Ni-filter) with $\mathrm{CuK} \alpha=$ $1.54051 \AA$ on a diffracted beam in a step-by-step mode with a pulse-recruitment time of $10 s$ and a step size of $0.02^{\circ}$ in the $2 \Theta$ range $2 \ldots 80^{\circ}$.

Qualitative analysis of the diffractogram was conducted using the PDF-2 and COD databases. Based on this it can be said that the concentrate of iron ore is magnetite (diffraction reflections at $2 \Theta \sim 36^{\circ}, \sim 57^{\circ}, \sim 63^{\circ}$ ), in which

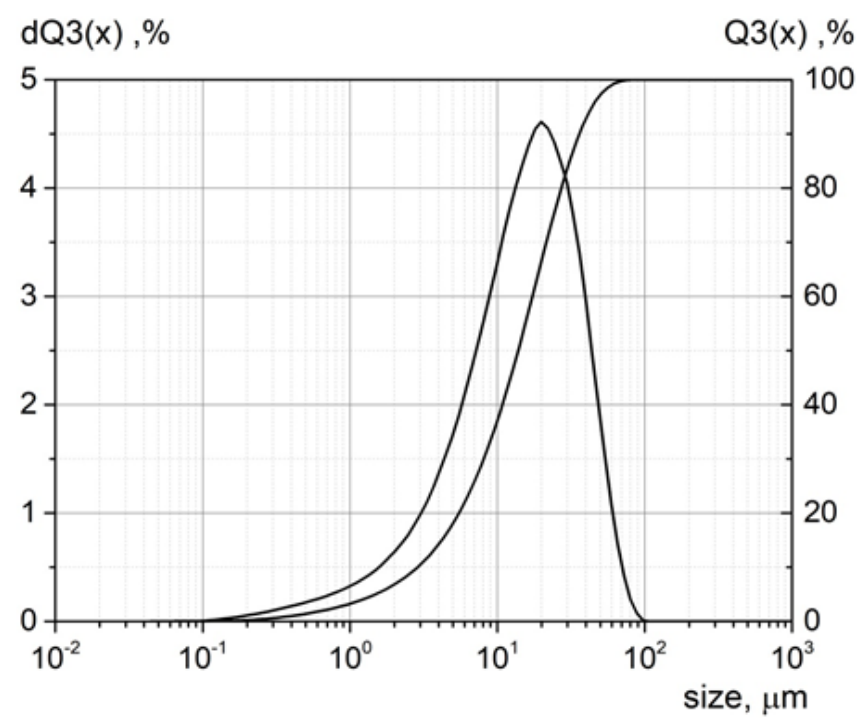

Fig. 1. Differential and cumulative grading curve of particles distribution of iron-ore concentrate powder.

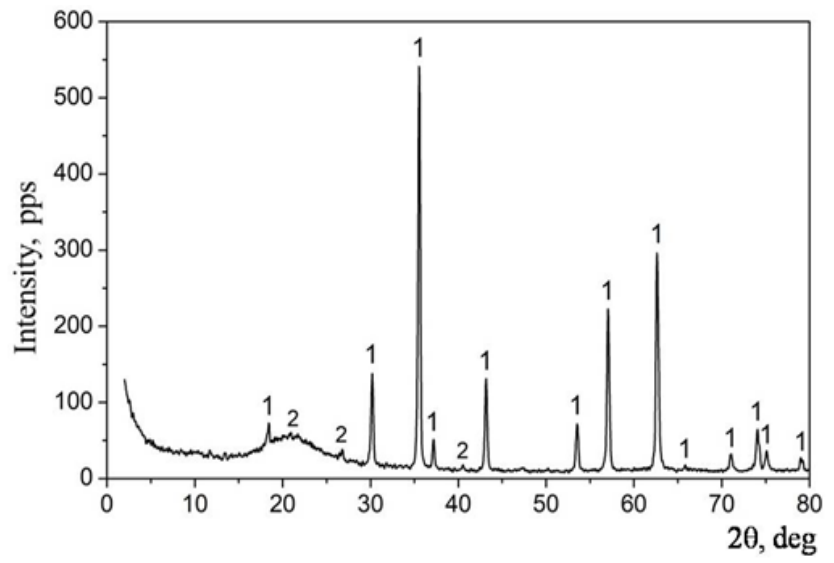

Fig. 2. Diffraction pattern of iron-ore concentrate: 1 - phase $\mathrm{Fe}_{3} \mathrm{O}_{4} ; 2$ - phase $\mathrm{SiO}_{2}$.

silicon oxide is present as the impurity phase (an amorphous halo is observed in angle range $2 \Theta \sim 16^{\circ}-26^{\circ}$ and diffraction reflections at $2 \Theta$ $\sim 27^{\circ}, \sim 41^{\circ}$, characteristic for quartz [10]) in an amount of about $5-6 \%$ (the content of silicon oxide, determined by semi-quantitative analysis of diffraction pattern using the software Match, the content of silicon oxide in the concentrate, according to data provided by «Lebedinskii ore mining and processing enterprise», $2.79 \%$ - see Table 1).

The cubic lattice parameter, calculated from the most intense reflections, is $a=8.39113$ (0.00289). The average crystallite size, calculated from the Scherrer formula, is $D \approx 230 \AA$.

Magnetite belongs to the family of ferrites (spinel). The cubic crystal lattice of spinel is formed by oxygen anions $\mathrm{O}_{2}$, with which $\mathrm{Fe}^{3+}$ and $\mathrm{Fe}^{2+}$ cations are connected. In this case, iron cations can be surrounded by four anions $\mathrm{O}^{2-}$ (tetrahedron) and six anions $\mathrm{O}^{2-}$ (octahedron). Accordingly, magnetite has a crystal structure of reversed spinel: $\left(\mathrm{Fe}^{3+}\right)$ $\left[\mathrm{Fe}^{2+} \mathrm{Fe}^{3+}\right] \mathrm{O}_{4}$. In the first part of the structure $-\left(\mathrm{Fe}^{3+}\right)$ there are cations only with valence +3 , and in the second part $-\left[\mathrm{Fe}^{2+} \mathrm{Fe}^{3+}\right]$ cations are twice as large and they have valence of both $2^{+}$and $3^{+}$.

Unlike ferromagnets, magnetite has a high resistivity value, a lower saturation induction value, and a more complex temperature dependence of induction. Magnetite is a 
semiconductor, the specificelectricalconductivity of monocrystalline magnetite is maximum at room temperature $\left(250 \mathrm{Ohm}^{-1} \cdot \mathrm{cm}^{-1}\right)$, it decreases rapidly with decreasing temperature, reaching a value of about $50 \mathrm{Ohm}^{-1} \cdot \mathrm{cm}^{-1}$ at the temperature of the Vervey transition (phase transition from cubic to low - temperature monoclinic structure existing below $T_{V}=120$ $125 \mathrm{~K})$.

Ferromagnetism in metals is formed between contacting atoms. In magnetite, magnetoactive cations are far from each other, because they are separated by oxygen anions that do not have a magnetic moment, and the direct exchange interaction between the cations is very weak or absent (indirect exchange).

Due to the high electrical resistivity, magnetite has low eddy current losses. Saturation induction is approximately $20-25 \%$ of iron saturation induction.

Investigated samples were obtained in four stages. Rubber masterbatch, that consist from butadiene-styrene rubber and magnetite in ratio 1:3, were prepared in laboratory mill, tentatively. The remaining components included in the composition (Table 2) were mixed with the masterbatch in a laboratory rubber mixer for 6 minutes at a temperature of $T=60^{\circ} \mathrm{C}$. The finished mixtures were processed on laboratory mill.

Purpose of the components of the curing system, which given in Table 2 , is as follows:

- Technical stearic acid, $\mathrm{C}_{17} \mathrm{H}_{35} \mathrm{COOH}$ (GOST 6484-96) - vulcanization activator, plasticizer, disperser;

Table 2. Rubber-stock formula for composites based on SCS30 ARC with magnetite filler.

\begin{tabular}{|c|c|c|c|c|c|c|c|}
\hline \multirow{2}{*}{ Comp. } & \multicolumn{7}{|c|}{ Comples } \\
\cline { 2 - 8 } & RM.1 & RM.2 & RM.3 & RM.4 & RM.5 & RM.6 & RM.7 \\
\hline SCS-30 ARC & 100.0 & 100.0 & 100.0 & 100.0 & 100.0 & 100.0 & 100.0 \\
\hline Stearic acid & 1.5 & 1.5 & 1.5 & 1.5 & 1.5 & 1.5 & 1.5 \\
\hline ZnO & 5.0 & 5.0 & 5.0 & 5.0 & 5.0 & 5.0 & 5.0 \\
\hline S & 2.0 & 2.0 & 2.0 & 2.0 & 2.0 & 2.0 & 2.0 \\
\hline Altax & 3.0 & 3.0 & 3.0 & 3.0 & 3.0 & 3.0 & 3.0 \\
\hline Magnetite & 0.0 & 10.0 & 30.0 & 50.0 & 100.0 & 200.0 & 300.0 \\
\hline
\end{tabular}

- Zinc oxide, $\mathrm{ZnO}$ (GOST 202-84) vulcanization activator;

- Sulfar, S (GOST 127.4-93) - vulcanizing agent;

- Altax, 2,2'-Dibenzothiazoldisulphide, $\mathrm{C}_{14} \mathrm{H}_{8} \mathrm{~N}_{2} \mathrm{~S}_{4}$ (GOST 7087-75) - vulcanizing agent and vulcanization accelerator;

- Magnetite, $\mathrm{Fe}_{3} \mathrm{O}_{4}$ (Technical Specifications 0712-030-001186803-99) - functional filler for increase the electrical conductivity, dielectric permittivity and dielectric loss angle tangent, to give magnetic properties for composites.

Prepared mixtures with magnetite content $C=0 . .300$ weight parts (w.p.) were cured in hydraulic press during that time shown in Table 2 at a temperature of $T=160^{\circ} \mathrm{C}$. As a result, smooth elastic plates with a thickness of $1 \mathrm{~mm}$ were obtained.

In this work were investigated concentration dependencies of following parameters: tensile strength, breaking elongation, volume resistivity, dielectric permittivity and dielectric loss angle tangent on some frequencies, reflection loss, transmission coefficient and loss coefficient in the frequencies range $25.86 \ldots 35.7 \mathrm{GHz}$.

Stress-strain properties of materials were determined by universal testing system Instron 3365. Tentatively, samples for testing were cut from plates with millimeter thickness by cutting die with work sector width equal $5 \mathrm{~mm}$, and work sector length equal $35 \mathrm{~mm}$. Sample thickness were determined at three points by micrometer, and average value were calculated. Stretching of the samples were conducted at a tensile testing grip speed of $500 \mathrm{~mm} / \mathrm{min}$. Tensile strength $\sigma_{\mathrm{p}}, \mathrm{MPa}$ and breaking elongation $\varepsilon_{\mathrm{p}}, \%$ were calculated from the test results [12]:

$$
\begin{aligned}
& \sigma_{p}=\frac{P_{p}}{d \cdot b_{0}}, \\
& \varepsilon_{p}=\frac{l_{p}-l_{0}}{l_{0}} \cdot 100,
\end{aligned}
$$

where $P_{b}-$ is force, which is a cause of sample breaking, $N ; d-$ is mean of sample thickness, 
before measurement, $m ; b_{0}-$ is sample width, before measurement, $m ; l_{b}-$ is length between marks at breaking moment of sample, $m m$; $l_{0}-$ is lengh between marks of sample, before measurement, $\mathrm{mm}$.

Volume resistivity $\left(\rho_{V}, \Omega \cdot m\right)$ of samples plates were determined by high resistance meter Agilent 4339B with resistivity cell 16008B. Clamping device of cell provides a tight contact between electrode and sample surface. The value of sample resistivity were measured after storage during that 6 minutes at voltage equal $100 \mathrm{~V}$. Sample thickness were determined at six points by micrometer, and average value were calculated. Calculation of $\rho_{V}$ were made with formula:

$$
\rho_{V}=\frac{R \cdot S}{L}
$$

where $\mathrm{R}-$ is measured sample resistivity, $\Omega ; S$ - is surface area of electrods, $m^{2} ; L-$ is sample thickness, $m$.

Dielectric parameters were determined by precision LCR Meter Agilent E4980A with dielectric test fixture $16451 \mathrm{~B}$. The value of gap between electrodes had been determined by built-in micrometer. The determination technique of relative dielectric permittivity $\varepsilon$ is based on depend dielectric permittivity of material between electrodes upon capacity of parallel-plate capacitor [13]. The amount of $\varepsilon$ is calculated with formula:

$$
\varepsilon=\frac{C_{\varepsilon} \cdot d}{\varepsilon_{0} \cdot S}=\frac{\left(C_{x}-C_{p}\right) \cdot d}{\varepsilon_{0} \cdot S},
$$

where $C_{x}-$ is measured capacity, $F ; C_{p}-$ is correction, which consist of the amount parasitic and lateral capacitance of measuring capacitor, $F ; d$ - is value of gap between electrodes, sample thickness, $m ; \varepsilon_{0}-$ is dielectrical constant equal $8.854 \cdot 10^{-12} \mathrm{~F} / \mathrm{m} ; \mathrm{S}-$ is area of electrodes of parallel-plate capacitor, $m^{2}$.

The dielectric loss angle tangent $\operatorname{tg} \delta_{\varepsilon}$ of investigation composites were calculated with formula:

$$
\operatorname{tg} \delta_{\varepsilon}=\operatorname{tg} \delta_{x} \cdot \frac{C_{x}}{\left(C_{x}-C_{p}\right)},
$$

where $\operatorname{tg} \delta_{\mathrm{x}}-$ is measured value of dielectric loss angle tangent of measuring capacitor.

A series of studies of microwave absorption properties of investigation materials has been conducted. Investigation of reflection loss $R$ $(d B)$ and transmission coefficient $T(d B)$ in the frequencies range of 25.86 to $37.5 \mathrm{GHz}$ were determined by vector network analyzer Anritsu MS4644A with guided-wave measurement cell. Calculation of reflection, transmission and losses coefficient has been produced with formula (Fig. 3):

$$
T=\frac{P_{\text {trans }}}{P_{\text {init }}}, R=\frac{P_{\text {refl }}}{P_{\text {init }}}, L=\frac{P_{\text {loss }}}{P_{\text {init }}}=1-T-R,
$$

where $P_{\text {init }}-$ is initial wattage of EMI, $W ; P_{\text {trans }}$ - is transmission wattage of EMI, $W ; P_{\text {refl }}-$ is reflection EMI wattage, $W$; $P_{\text {loss }}-$ is losses of EMI wattage in material, $W$.

Magnetic properties of obtained composites were investigation by magnetometer. Magnetization curves of samples upon magnetic field strength $5 \mathrm{kOe}$ were plotted by automatic vibromagnitometer EG\&G PAR-155. Discs with a diameter of about five millimeters and thickness of about one millimeter have been cut from composite plates. Discs was glued to holder by glue BF-2.

Interesting from the point of view of practical applications is the possibility to control the reflection coefficient from magnetoelastomeric composite using a magnetic field. Such

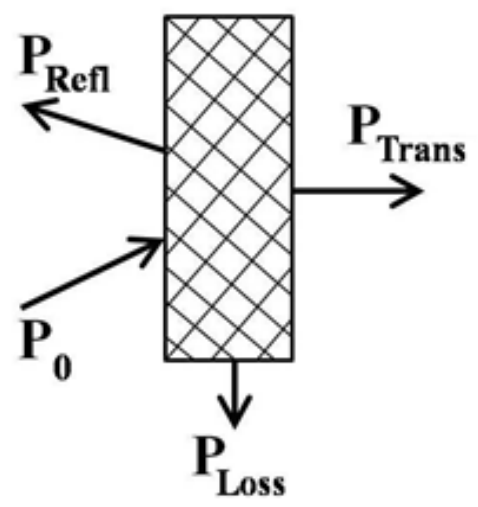

Fig. 3. Scheme of interaction of samples with EMI. 


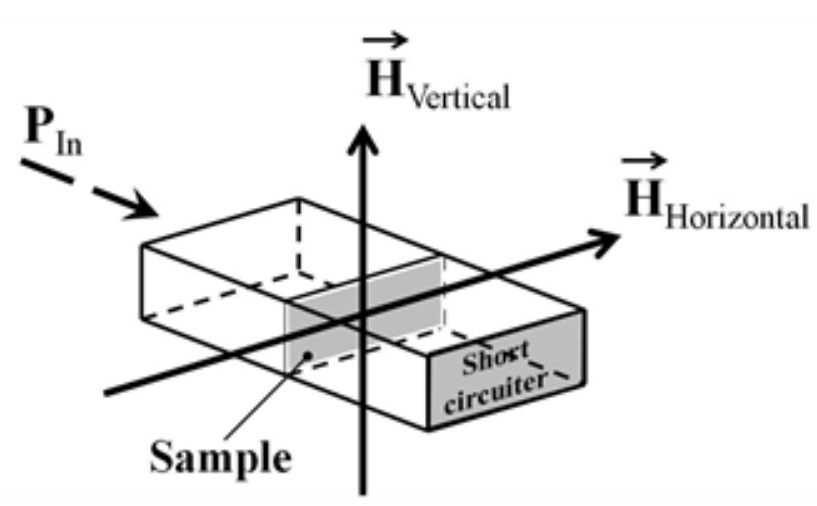

Fig. 4. The scheme of inclusion of the sample in the measuring microwave path with an external magnetic field.

measurements were performed according to the scheme shown in Fig. 4.

The sample was placed in a short-circuited section of the waveguide path with a cross section of $7.2 \times 3.4 \mathrm{~mm}$ (operating frequency band 25.86...37.5 $\mathrm{GHz}$, the main wave type $\mathrm{TM}_{01}$ ). The magnetic field of $0.4 \mathrm{~T}$ has been created by two permanent magnets of high-coercive $\mathrm{NdFeB}$ alloy. The amplitude and phase of the scattering matrix coefficient $S_{11}$ (back reflection to the generator) at different directions of the magnetic field vector were measured using a vector analyzer Anritsu MS-4644A.

\section{RESULTS AND DISCUSSION}

Most important parameter to achieve strengthen effect of materials is interfacial area between rubber matrix and filler particles. Interfacial area of rubber/filler depends on particle size and filler concentration. Key parameter for definition of gain rate rubber is amount of physical-chemical bonds between rubber matrix and filler particles.

The stress-strain measurements results for materials based on butadiene-styrene rubber and magnetite have been illustrated in Fig. 5 .

Measurements on extension at tension showed that increase of filler concentration result to increase elasticity modulus at extension and decrease of extension elongation. This improvement of stress-strain properties is due to mobility limiting of polymeric chain in rubber (resulted from distribution of filler particles and interaction with them).

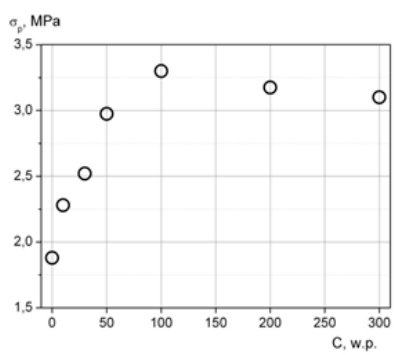

$a$

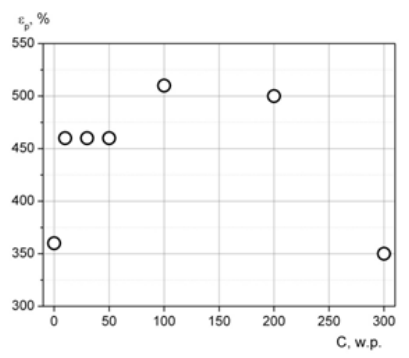

b
Fig. 5. Dependence of stress-strain properties of elastomeric composites on the filler content: a) tensile strength; b) breaking elongation.

Tensile strength is characterized by persistence to expansion of cracks in rubber. Addition of filler particles significantly increase tensile strength of elastomeric composites. Tensile strength for such materials is due to structure of elastomeric composites, strong interface interactions between filler particles and rubber matrix, also to ability to skid of aggregates during extension. In this case physical barriers is forming in the way of expansion of cracks and crack growing energy is decrease.

Composites have not only greater strength, but also greater hardness in comparison with unfilled materials. Increase of hardness is due to equal distribution of filler particles, which increase degree of interface interactions between filler particles and rubber matrix.

Strength is increasing to certain maximum, which depended of composition components nature, with growing of specific surface of highdispersity filler. In case of product with small thickness and difficult configuration preference is given to high-dispersity fillers (powders), because they are easy distributed in matrix, thereat saving iternal distribution during forming. Application of high-dispersity fillers decrease possibility of destruction, delamination of product during the next mechanical processing.

Solid impurities in extended sample are decreasing stress in the contact area between matrix and filler. For example, in spherical particles stress exceeds in one and a half stress in matrix bulk, in other words filler perceives the main part of stress. The influence of the filler increases, when particles have an ellipsoidal form and have been directed to axis of deformation. 
Generally strength of composite material is determined by intermolecular Van der Waals interactions and by bonding force of main chain of macromolecule in polymer matrix. When macromolecules is undirected (lowfilled composites), bounds is located at large angles to direction of applied stress. In this case macromolecule have a sufficient flexibility. Destruction of composite material in the direction of stress for the most part is carried out from separation of links and segments of macromolecule at them sliding relative to one another, results from mobility and different length of macromolecule chains. In case when filler increases strength of polymer composite, the amount of cross-links in the polymer network and the amount of bonds between nearest filler particles are increased. Breaking of this three-dimensional hard structure is carried out predominantly from breaking of bonds in main polymer chain. Polymer composites like other construction materials are destructed is due to progressing of initial defects. It should be noted that fact of filling leads to difficult technological defects in composite, which include cracks and pores, which is formed during production. These defects are formed as a result of collateral action by adding the filler in polymer matrix, this action causes the concentrating of stress on aggregates of particles and is a potentional reason of starting of distruction. Distribution of initial cracks in the bulk of polymer composite and them geometry of growing are depending of strengths relation and relation of thermal-expansion coefficients of matrix and filler. In this case, hemispherical cracks around filler particles, which later transition in matrix or cracks passing through matrix and particles (the most dangerous for product) are appearing. However filler particles plays a role not only initiator of cracks in composite. Individual particles able to brake and stop growing of cracks at small growing velocity of them. Such cracks, when they meets with particle, break adhesion bonds on the surface of contact between particle and matrix. Thus, the front of crack extends over and local stresses are redeployed in the area of matrix near interface.

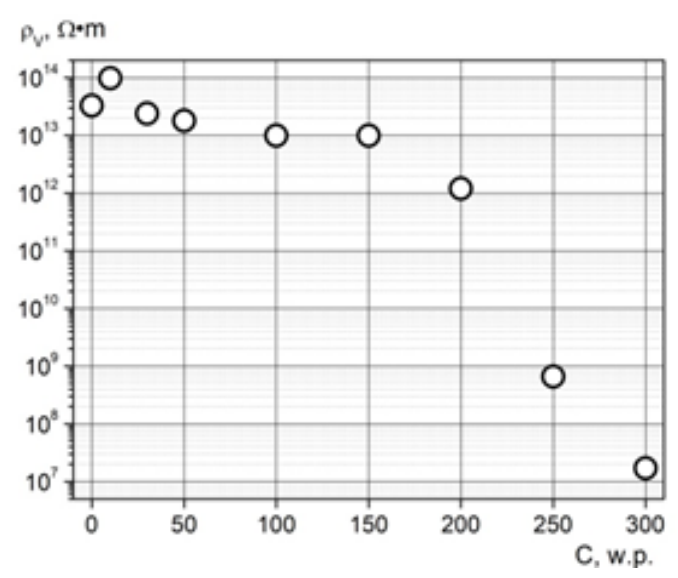

Fig. 6. Dependence of the volume resistivity $\rho_{V}$ of elastomeric composites on magnetite concentration.

As a result, the strain energy at the front of crack decreases and growing of the crack is stopped [14].

Thus, with increasing of filler concentration the strength characteristics $\sigma b$ and $\varepsilon b$ increases to a maximum at concentration $C=200$ w.p. Tensile strength slightly decreases at further increasing of magnetite contentration. The value of breaking elongation $\mathrm{bb}$ at concentration $C=300$ w.p. is comparable to the value of this parameter for unfilled vulcanizates. That means, that in investigated range of magnetite contentration composite saves satisfactory stress-strein properties.

The value of electrophysical parameters of elastomeric composites also changes at increasing of magnetite concentration $C$ : volume resistivity decreases (Fig. 6), dielectric permittivity $\varepsilon$ and dielectric loss angle tangent tg $\delta$ increases (Fig. 7).

The figure shows that the dependence of the permittivity and the dielectric loss tangent at values $C=200 \ldots 300$ w.p. at frequencies of 1 $\mathrm{kHz}$ and $1 \mathrm{MHz}$ are different. This effect may

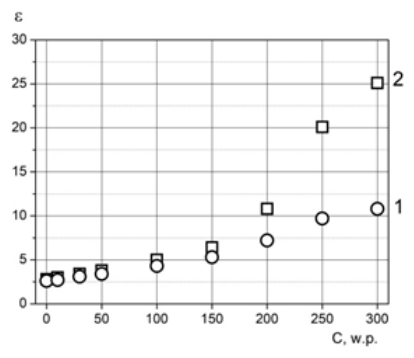

$a$

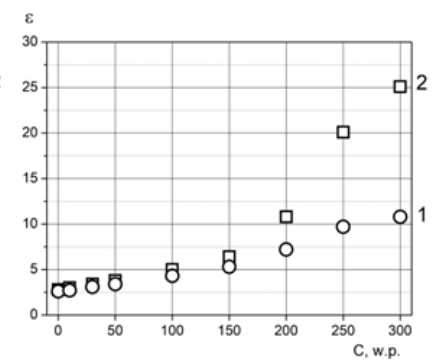

$b$
Fig. 7. Dependence of the $\varepsilon(a)$ and tg $\delta$ (b) increases of elastomeric composites on magnetite concentration at different working frequencies: 1) $1 \mathrm{KHz;}$ 2) $1 \mathrm{MHz}$. 
be related to wide distribution of filler particles on sizes which is related to aggregation of filler particles in clusters, as well as with a change in the nature of polarization and the mechanism of conductivity of the composite with increasing frequency. The conductivity of magnetite at a temperature above the temperature of the Vervey transition is explained by the presence of a variable valence and has a frequency dependence. In turn, the value of the electrical conductivity of polycrystalline magnetite, depending on the presence of cracks and their orientation may differ hundreds of times.

The results of measurement of reflection $R$, transmission $T$ and loss $L$ coefficients in dependence of magnetite concentration $C$ is shown on Fig. 8. Loss coefficient $L$ increases at growing of magnetite concentration $C$ that is due to increasing loss by electrical conductivity. The best shielding characteristics (minimum of transmistion coefficient and maximum of reflection coefficient) are observed in concentration range $C=100 \ldots .200$ w.p.

On the amplitude-frequency characteristic of the reflection coefficient of the sample measured in the configuration Fig. 4, there is an interference peak, the position $f$ and the intensity $A$ of which at different direction of the external magnetic field, as well as in its absence, are presented in the Table 3.

The application of an external magnetic field changes the magnetic susceptibility of a magnetically soft composites in the direction

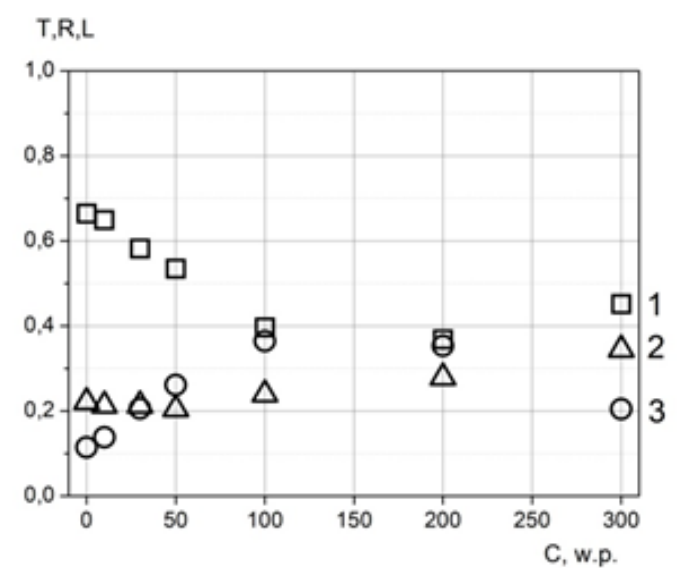

Fig. 8. Dependence of the transmission $T$ (squares), the loss $L$ (triangles) and the reflection $\mathrm{R}$ (circles) coefficients on the magnetite concentration $C$.
Table 3.

Influence of external magnetic field on reflection coefficient.

\begin{tabular}{|l|c|c|}
\hline & $f, \mathrm{GHz}$ & $A, d B$ \\
\hline Without external field & 36.4 & $-13.5 \pm 0.5$ \\
\hline Horizontal field & 36.4 & $-9.7 \pm 0.5$ \\
\hline Vertical field & 36.4 & $-14.8 \pm 0.5$ \\
\hline
\end{tabular}

of the magnetic field, which should affect the nature of the interaction with polarized electromagnetic radiation. The obtained results show the anisotropy of the reflection coefficient of magnetoelastics from the direction of the external magnetic field. Reduction of the magnetic susceptibility of the medium with the application of an external field should lead to a decrease in the reflectance of the sample and to an increase in the transmittance. The reflection from the sample increases with a horizontally applied magnetic field, since the vector of the magnetic field of the wave in the waveguide is also directed horizontally. This effect can also be used in multilayer structures [16].

Magnetization curves for composites are shown on Fig. 9. The absence of hysteresis on magnetization curves for composites makes it possible to classify the investigated materials to class low-coercivity materials. The saturation magnetization $\sigma S$ in this materials is achieved in magnetic fields $4 \mathrm{kOe}$ and increases at growing of magnetite concentration. The similar results were obtained in a paper [15] for polyethylene/ nikel ferrite nanocomposites.

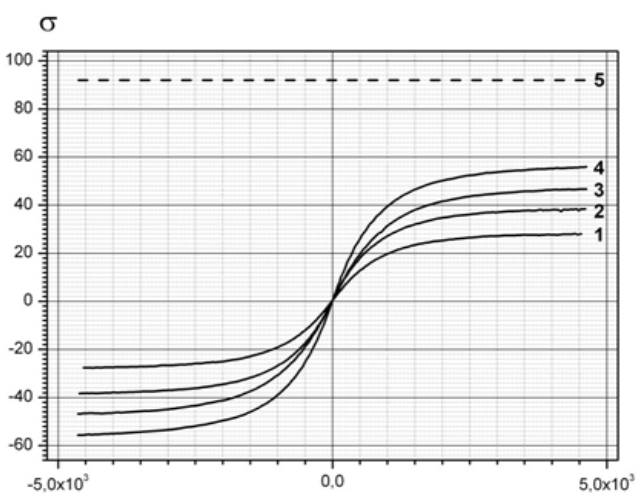

$\mathrm{H}$

Fig. 9. Magnetization curves for composites at different magnetite concentration C: 1 - 50 weight parts, 2 - 100 weight parts, 3 - 200 weight parts, 4 - 300 weight parts. 5 - level of specific saturation magnetization for pure magnetite [17]. 
FUNCTIONAL ELASTOMERIC MATERIALS BASED ON

\section{CONCLUSION}

Thus, elastomeric composite materials based on butadiene-styrene matrix and magnetite are obtained. For them is shown, that:

- At increasing of magnetite concentration in butadiene-styrene rubber strength of vulcanizates increases reaching maximum at concentration 200 weight parts. Breaking elongation is changing similarly;

- The value of magnetite concentration at which is seen significant change of electrophysical parameters and also change of reflection and absorption coefficients is 100 weight parts;

- With increase of magnetite concentration the value of e and tgd grows (at frequensence 1 $\mathrm{MHz}$ from 2.5 to 12 and from 0.02 to 0.13 consequently) and volume resistivity decrease (from $10^{13}$ to $10^{7} \Omega \cdot \mathrm{m}$ );

- With increase of magnetite concentration saturation magnetization grows (for composites $\sigma_{\mathrm{s}}=27 \ldots 55$, that comparable with $\sigma_{\mathrm{s}}=92$ for pure magnetite);

- There is an anisotropy of the reflection coefficient of magnetically elastomeric composite materials from the direction of the external magnetic field.

Elastomeric composites based on butadienestyrene matrix and magnetite have the next advantages: flexibility, adaptability to manufacture, cost-efficiency, well stress-strain properties. This materials can be used as a screens reflecting EMR, microwave absorption materials, antistatic materials, magnetorheological materials, including materials with controlled parameters. For improving of characteristics are recomended: choose a optimal dispersability of magnetite, master a technique of producing magnetostructural materials, correct a rubber-stock formula.

A promising direction in materials science is the synthesis of elastomeric nanocomposites based on nanophase fillers with different physical properties that can be effectively used not only as electrodynamic media, but also in acoustoelectronic devices [18, 19, 20]

\section{REFERENCES}

1. Kabanov V. Land rent. Polymer Encyclopedia. 2:325-332. Moscow, Sovetskaya entsiklopedia Publ., 1974.

2. Kon'kov VA, Polyakova KP, Polyakov VV. Magnitnye svojstva mul'tiferroika $\mathrm{Fe}_{3} \mathrm{O}_{4}$ [Magnetic properties of multiferroic $\mathrm{Fe}_{3} \mathrm{O}_{4}$ ]. Aktual'nye problemy aviatsii $i$ kosmonavtiki, 2011, 1(7):142-143 (in Russ.).

3. Russkikh GS. Raschetno-eksperimental'nye issledovaniya magnitouprugogo effekta $\mathrm{v}$ metallonapolnennykh elastomerakh [Calculation-experimental investigation of converse magnetostrictive effect in metalfilled elastomers]. Proc. 6 Mezhdunarodnoj nauchno-tekhnicheskoj konferentsii "Tekhnika i tekhnologiya neftekhimicheskogo $i$ neftegazovogo proizvodstva". Omsk, OSTU Publ., 2016, pp. 156-157 (in Russ.).

4. Gerval'd AYu, Gritskova IA, Prokopov NI. Sintez magnitsoderzhashchikh polimernykh mikrosfer [Synthesis of magnet-containing polymeric microspheres]. Uspekhi khimii, 2010, 79(3):249-260 (in Russ.).

5. Caruso F, Susha AS. Magnetic coreshell particles: preparation of magnetite multilayers on polymer latex microspheres. Advanced materials, 1999, 11(11):950-952.

6. Gomez-Lopera SA, Plaza RC. Synthesis and characterization of spherical magnetite/ biodegradable polymer composite particles. Journal of colloid and interface science, 2001, 240(1):40-47.

7. Pastukhov AV, Davankov VA, Volkov VV. Magnitnye nanokompozity na osnove sverkhsshitykh polistirolov [Magnetic nanocomposites based on hypercrosslinked polystyrene]. Iqvestiya rossiyskoy akademii nauk. Seriya fizicheskaya, 2009, 73(4):496-498 (in Russ.).

8. Lubentsova KI, Pastukhov AV, Davankov VA. Sorbtsiya toksichnykh organicheskikh i neorganicheskikh soedinenij kompozitami $\mathrm{s}$ nanodispersnymi oksidami zheleza V matritsakh polistirol'nykh sorbentov [Sorption of toxic organic and inorganic compounds by 
composites which contain nanosized ferrum oxides in the matrix of polystyrene sorbent]. Sorbtsionnye i kbromatograficheskie protsessy, 2015, 15(3):333-334 (in Russ.).

9. Ing Kong, Sahrim Hj Ahmad. Magnetic and microwave absorbing properties of magnetite-thermoplastic natural rubber nanocomposites. Journal of Magnetism and Magnetic Materials, 2010, 322(21):3401-3409.

10. Borisov LA, Grishin YuM, Kozlov NP at all. Patent 2516512 Rossijskaya Federatsiya, MPK7 C 30 B 30/02, C 30 B 29/06. Sposob pryamogo polucheniya polikristallicheskogo kremniya iz prirodnogo kvartsa i iz ego osobo chistykh kontsentratov [The technique of directly obtaining of polycrystalline silicon from natural silica and its high purity concentrate]. N 2012128656/05; zayavl. 09.07.12; opubl. 20.05.14, Byull. N 14, 2014.

11. Severov VV. Razrabotka protsessa obratnoj flotatsii zhelezistykh kvartsitov s ispol'zovaniem kationnykh i neionogennykh sobiratelej [The develop of reverse flotation process of ferruginous quartzite with using cation and non-ionogenic collector]. Dis. ... kand. tekhn. nauk, 25.00.13. Natsional'nyj issledovatel'skij tekbnologichesk ij universitet «MISiS». Mocsow, 2011, 215 p.

12. Rezina. Obshchie trebovaniya $\mathrm{k}$ provedeniyu fiziko-mekhanicheskikh ispytaniy. Rubber. Common requirements to holding of stressstrain testing. GOST 269-66, Moscow, 2001,11 p.

13. Lushchejkin GA. Metody issledovaniya elektricheskikh svojstv polimerov [Techniques of investigation the electrophysical properties of polymers]. Moscow, Khimiya Publ., 1988.

14. Kiseleva OA (compiler). Polistrukturnaya teoriya prochnosti kompozitsionnykh materialov [The polystructural theory for strength of composite materials] (metod. ukaz.). Tambov, TGTU Publ., 2013, 22 p.

15. Fionov AS, Kolesov VV, Yurkov GYu. Kompozitsionnye materialy na osnove nanochastits $\mathrm{NiFe}_{2} \mathrm{O}_{4}$ i polietilenovoj matritsy [Composite materials based on nanoparticles $\mathrm{NiFe}_{2} \mathrm{O}_{4}$ and polyethylene matrix]. Materialy 20 Mę̧bdunarodnoj Krymskoj konferentsii «SVCH-tekhnika i telekommunikatsionnye tekhnologii» (KryMiKo 2010). 13-17 Sept., 2010, Sevastopol', Krym, Ukraina, pp.769-770.

16. Gorshenev VN, Kolesov VV, Fionov AS, Erichman NS. Mnogosloynye pokrytiya s izmenyaemymi elektrodinamicheskimi kharakteristikami na osnove napolnennykh polimernykh matrits [Multilayer coatings with variable electrodynamic characteristics based on filled polymer matrix]. Zhurnal radioelektroniki, ISSN 1684-1719, 2016, 11:118 (in Russ.).

17. Babichev AP at all (eds.). Fizicheskie velichiny: Spravochnik [Physical magnitudes: handbook]. Moscow, Energoatomizdat Publ., 1991.

18. Kuznetsova IE, Zaitsev BD, Shikhabudinov AM. Elastic and viscous properties of nanocomposite films based on lowdensity polyethilene. IEEE Transactions on Ultrasonics, Ferroelectric and Frequency Control, 2010, 57(9):2099-2102, DOI: 10.1109/ TUFFC.2010.1658.

19. Kuznetsova IE, Zaitsev BD, Shikhabudinov AM. Effect of the nanoparticle material density on acoustic parameters of polymerbased nanocomposites. Technical Physics Letters, 2010, 36(8):759-761, DOI: 10.1134/ S1063785010080249.

20. Kuznetsova IE, Zaitsev BD, Borodina IA, Shikhabudinov AM, Teplykh AA, Manga E, Feuillard G. The Effect of Nanocomposite Polymeric Layer on the Radiation of Antisymmetric Zero-Order Lamb Wave in a Piezoelectric Plate Contacting with Liquid. Journal of Applied Physics, 2013, 113:224507, DOI: $10.1063 / 1.4810905$. 